\title{
Problemy elektrofizjologiczne i neurologiczne u młodego pacjenta z wrodzonym skorygowanym przełożeniem wielkich pni tętniczych
}

\author{
Electrophysiological and neurological problems in young patient \\ with corrected congenital transposition of the great arteries
}

\author{
Andrzej Wojtarowicz, Beata Izabela Bania \\ Klinika Kardiologii Pomorskiego Uniwersytetu Medycznego w Szczecinie
}

\section{Streszczenie}

Przedstawiono przypadek pacjenta z rozpoznanym, dobrze tolerowanym, wrodzonym skorygowanym przełożeniem wielkich pni tętniczych i wrodzonym blokiem przedsionkowo-komorowym III stopnia. W wieku 26 lat wystapił u niego zespół Morgagniego-Adamsa-Stokesa z urazem czaszki, a w następnym roku przebył zator mózgowy jako powikłanie świeżo ujawnionego migotania przedsionków.

Słowa kluczowe: wrodzone skorygowane przełożenie wielkich pni tętniczych, zaburzenia rytmu i przewodzenia, stymulacja serca dwujamowa, niewydolność serca

Folia Cardiologica 2016; 11, 5: 477-479

\section{Wstęp}

Wrodzone skorygowane przełożenie wielkich pni tętniczych (ccTGA, congenitally corrected transposition of the great arteries) jest rzadką wadą serca. Jej istota to przejęcie przez anatomicznie prawą komorę roli komory systemowej, a przez komorę anatomicznie lewą - roli komory płucnej. W izolowanej postaci wada długo może pozostawać bezobjawowa, jednak w jej przebiegu często pojawiają się zaburzenia rytmu i przewodzenia wymagające interwencji, a także niewydolność komory systemowej $[1,2]$.

\section{Opis przypadku}

Pacjent w wieku 26 lat, z ustalonym rozpoznaniem ccTGA i z wrodzonym blokiem przedsionkowo-komorowym (AV, atrioventricular) III stopnia został w wieku przyjęty do kliniki kardiologii po pełnym omdleniu z urazem głowy, bez zmian w badaniach obrazowych i badaniu neurologicznym. Od około 2 tygodni odczuwał osłabienie, bóle głowy, mroczki przed oczami. Negował wcześniejsze zasłabnięcia i omdlenia, nie odczuwał również upośledzenia wydolności wysiłkowej (I klasa wg New York Heart Association [NYHA]). Podczas obserwacji w klinice nie wykazano objawów związanych z bradykardią. Przedmiotowo stwierdzono: ranę tłuczoną okolicy potylicznej, ciśnienie tętnicze (RR) 150/85 mm Hg, tętno (HR, heart rate) około 40/min i szmer skurczowy nad tętnicą płucną oraz w punkcie Erba. W zapisie elektrokardiograficznym (EKG) stwierdzono: miarowy rytm zatokowy ok 80/min, blok AV III stopnia z zastępczym rytmem komór z wąskimi zespołami QRS około 40/min. W badaniu echokardiograficznym (ECHO) uwidoczniono typowe cechy ccTGA (ryc. 1, 2) - po lewej stronie komorę systemową o cechach prawej komory,

Adres do korespondencji: dr hab. n. med., prof. PUM Andrzej Wojtarowicz, Klinika Kardiologii, Pomorski Uniwersytet Medyczny, Al. Powstańców Wielkopolskich 72,70-111 Szczecin, tel. 9146613 77, faks 9146613 79, e-mail: wojtaro@pum.edu.pl 


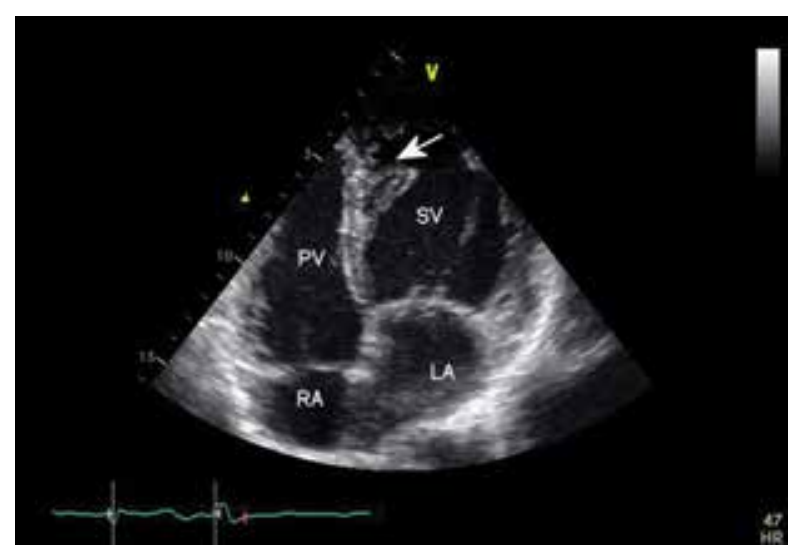

Rycina 1. Typowy obraz wrodzonego skorygowanego przełożenia wielkich pni tętniczych (strzałka pokazuje wiązkę pośrednią; SV (systemic ventricle) - komora systemowa; PV (pulmonary ventricle) - komora płucna; LA (left atrium) - lewy przedsionek; RA (right atrium) - prawy przedsionek

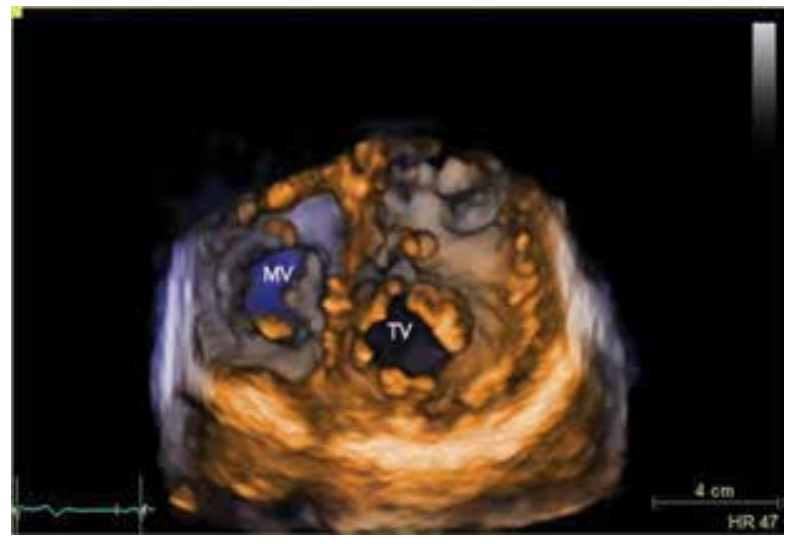

Rycina 2. Badanie 3D: między lewym przedsionkiem a komora systemową znajduje się zastawka trójdzielna (TV, tricuspid valve), a między prawym przedsionkiem a komorą płucną - zastawka dwudzielna (MV, mitral valve) poszerzoną do $63 \mathrm{~mm}$ w rozkurczu, o znacznym przeroście, z dość dobrą kurczliwością (frakcja wyrzutowa [EF, ejection fraction] 45\%). Łączyła się ona z lewym przedsionkiem poprzez zastawkę trójpłatkową o umiarkowanej niedomykalności. Od tej komory odchodziła aorta. Po prawej uwidoczniono komore płucną o morfologii lewokomorowej, nieposzerzoną, z zastawką dwudzielną oraz odchodzącą od niej tętnicę płucną. Przedsionki były nieposzerzone. W EKG holterowskim zarejestrowano średnią HR około 46/min, minimalną 28/min (w godzinach nocnych). Istotnych pauz, do 5,2 s, zanotowano 15 niezależnie od pory doby (ryc. 3). Pacjenta zakwalifikowano do wszczepienia stymulatora, na co nie wyraził zgody. Po kilku miesiącach choremu implantowano dwujamowy stymulator serca w Instytucie Kardiologii w Warszawie. W kontrolnym badaniu EKG metodą Holtera stwierdzono dominujący rytm zatokowy, z okresowo widoczną stymulacją przedsionkową, komorową sterowaną rytmem przedsionków oraz przedsionkowo-komorową, napady częstoskurczu nadkomorowego z prawidłową reakcją stymulatora i 824 dodatkowe pobudzenia komorowe, w tym 13 par; włączono lek beta-adrenolityczny. W ECHO uwidoczniono elektrody w prawym przedsionku i komorze „płucnej”; końcówka elektrody komorowej przylegała do przegrody międzykomorowej (IVS, interventricular septum) (ryc. 4). Parametry anatomiczne serca nie różniły się od wyjściowych. Samopoczucie pacjenta było bardzo dobre; poprawiła się tolerancja wysiłku. W październiku 2014 roku wystąpił niedokrwienny udar mózgu z niedowładem połowiczym lewostronnym - pacjenta hospitalizowano w klinice neurologii, gdzie stwierdzono nierozpoznane wcześniej migotanie przedsionków i wdrożono leczenie przeciwkrzepliwe. W dalszej obserwacji objawy neurologiczne ustąpiły. W październiku 2015 roku wykonano kardiowersję elektryczną, uzyskując powrót rytmu zatokowego. Od tego czasu nie zanotowano napadów migotania przedsionków. Chory przewlekle przyjmuje leki antykoagulacyjne.

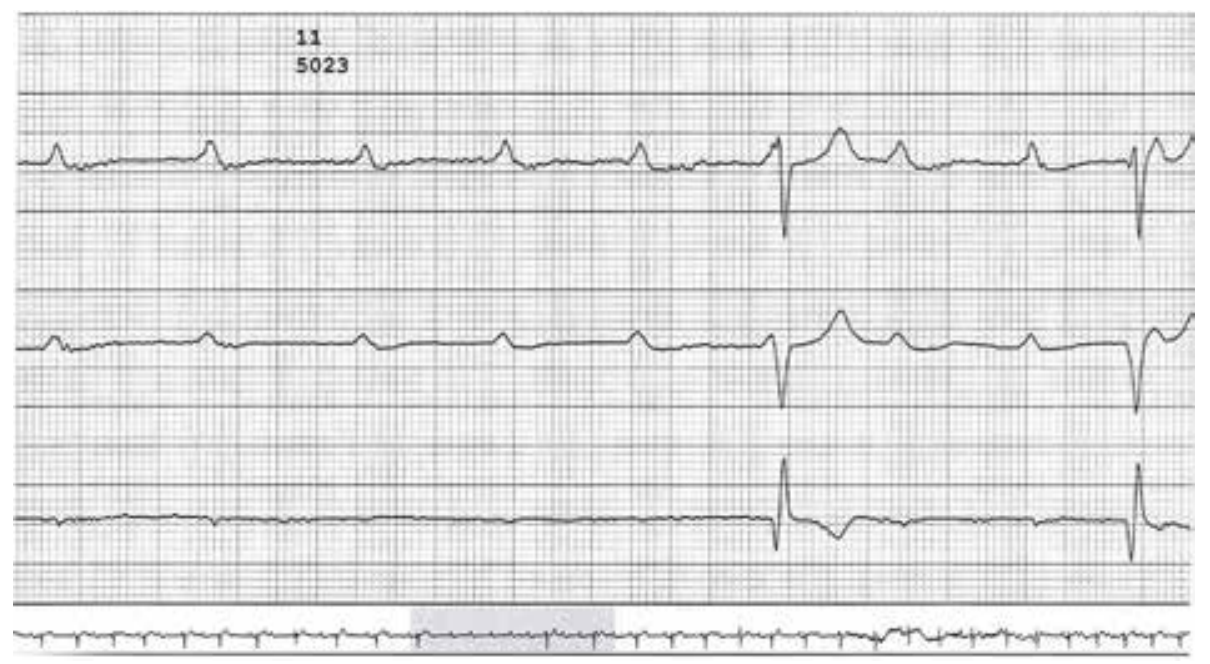

Rycina 3. Badanie holterowskie: blok przedsionkowo-komorowy III stopnia z pauzą między kolejnymi pobudzeniami komór powyżej $5 \mathrm{~s}$ 


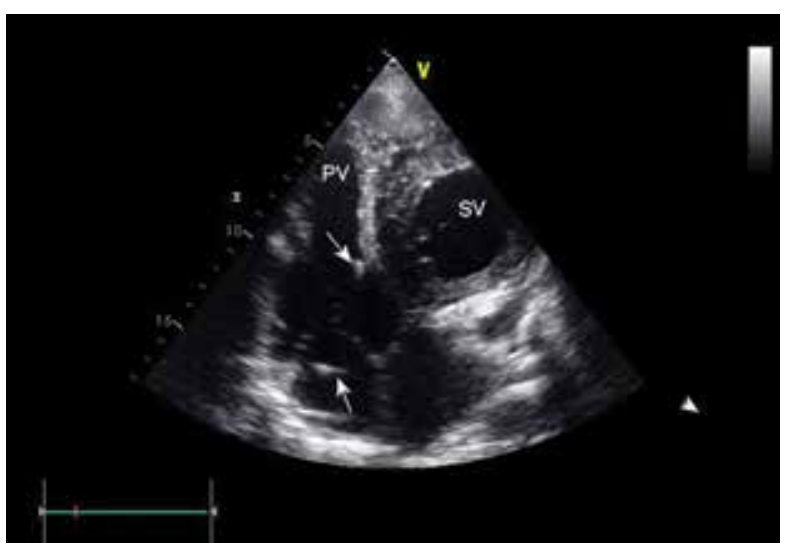

Rycina 4. Strzałkami wskazano elektrody stymulatora w prawym przedsionku i komorze płucnej (PV, pulmonary ventricle); SV (systemic ventricle) - komora systemowa

\section{Omówienie}

Wrodzone skorygowane przełożenie wielkich pni tętniczych stanowi mniej niż $1 \%$ wrodzonych wad serca. W wadzie tej układowa krew żylna przepływa z prawego przedsionka przez zastawkę dwudzielną do komory płucnej - anatomicznie lewej, a następnie do pnia płucnego przesuniętego do tyłu. Krew żylna z płuc napływa do lewego przedsionka, skąd przez zastawkę trójdzielną dostaje się do lewostronnie położonej komory systemowej - anatomicznie prawej, a następnie do aorty przemieszczonej do przodu i w lewo. Krążenie jest „fizjologicznie” skorygowane, a krążenie systemowe - obsługiwane przez komorę morfologicznie prawą. Charakterystyczne jest nieprawidłowe umiejscowienie węzła AV i pęczka Hisa, co prowadzi do zaburzeń przewodzenia. Około $5 \%$ chorych ma wrodzony całkowity blok AV. Zaburzenia przewodzenia u pozostałych mogą również wystąpić później. Zwykle w późniejszym okresie pojawiają się także różnego typu arytmie nadkomorowe i komorowe wymagające odpowiedniej terapii [3]. Postać izolowana dość długo może nie mieć następstw hemodynamicznych ani klinicznych [4]. Diagnozę czasem stawia się dopiero w wieku dorosłym lub nawet bardzo zaawansowanym $[5,6]$. U większości chorych z latami narasta niewydolność komory systemowej - u omawianego pacjenta do tej sytuacji jednak nie doszło. Zaawansowany wiek osiąga jedynie niewielka grupa chorych; większość umiera w średnim wieku z powodu narastającej niewydolności serca lub następstw zaburzeń rytmu i przewodzenia.

\section{Konflikt interesów}

Autorzy deklarują brak konfliktu interesów.

\section{Abstract}

A case of patient with diagnosed, well tolerated corrected congenital transposition of the great arteries (ccTGA) and congenital third-degree atrioventricular block is presented. At the age of 26 he had Morgagni-Stokes-Adams attack associated with cranial trauma, next year he developed cerebral embolism as a complication of newly diagnosed atrial fibrillation.

Key words: congenital transposition of the great arteries, cardiac arrhythmia, conduction abnormalities, biventricular pacing, heart insufficiency

Folia Cardiologica 2016; 11, 5: 477-479

\section{Piśmiennictwo}

1. Warnes C.A., Williams R.G., Bashore T.M. i wsp. ACC/AHA 2008 guidelines for the management of adults with congenital heart disease. Circulation 2008; 118: e714-e833.

2. Baumgartner H., Bonhoeffer P., De Groot F. i wsp. Wytyczne dotyczące leczenia dorosłych pacjentów z wrodzonymi wadami serca. Kardiol. Pol. 2010; supl. IX: 639-696.

3. Hofferberth S.C., Alexander M.E., Mah D.Y. Impact of pacing on systemic ventricular function in L-transposition of the great arteries. J. Thorac. Cardiovasc. Surg. 2016; 151: 131-139.
4. Sim M.M. Adaptation of the systemic right ventricle in a congenitally corrected transposition of the great arteries. Circulation 2013; 127: e448-e450.

5. Kowalik E., Jakubowska E., Hoffman P. Congenitally corrected transposition of the great arteries in a 72 year old man - a case report. Kardiol. Pol. 2004; 61: 56-58.

6. Wissocque L., Mondésert B., Dubart A.E. Late diagnosis of isolated congenitally corrected transposition of the great arteries in a 92-year old woman. Eur. J. Cardiothorac. Surg. 2016; 49: 1524-1525. 